\title{
Oil-Price Volatility and Macroeconomic Spillovers in Central and Eastern Europe: Evidence from a Multivariate GARCH Model
}

\author{
Scott W. Hegerty *
}

\begin{abstract}
Recent commodity price declines have added to worldwide macroeconomic risk, which has had serious effects on both commodity exporters and manufacturers that use oil and raw materials. These effects have been keenly felt in Central and Eastern Europe-particularly in Russia, but also in European Union member states. This study tests for spillovers among commodity-price and macroeconomic volatility by applying a VAR(1)-MGARCH model to monthly time series for eight CEE countries. Overall, we find that oil prices do indeed have effects throughout the region, as do spillovers among exchange rates, inflation, interest rates, and output, but that they differ from country to country - particularly when different degrees of transition and integration are considered. While oil prices have a limited impact on the currencies of Russia and Ukraine, they do make a much larger contribution to the two countries' macroeconomic volatility than do spillovers among the other macroeconomic variables.
\end{abstract}

Keywords: Oil Prices; Volatility; Multivariate GARCH; Spillovers; Central/Eastern Europe

JEL Classification: F36

\section{Introduction}

With oil and other commodity prices declining since 2014, after large increases that began during the run-up to the 2008 financial crisis, economies throughout the world must continue to brace for strong economic impacts. In particular, revenue might decline for commodity exporters, but economies that rely more on manufacturing will also find themselves susceptible to increased terms-of-trade volatility and the associated macroeconomic risk. This is especially true for the Central and Eastern European (CEE) region, whose countries are either members of or closely connected to the European Union.

\footnotetext{
${ }^{*}$ Scott W. Hegerty is at Northeastern Illinois University, Department of Economics, Chicago, USA.
} 
The CEE region has long experienced macroeconomic "transmission" from its larger neighbors. Before the 2008 Global Financial Crisis, rising commodity prices and currencies that were often pegged to the Euro combined to "import" inflation and contribute to an unsustainable economic boom. Likewise, the 2008 crisis and collapsing commodity prices were associated with volatile output, price declines and general instability in the CEE region and elsewhere in the world. This study examines the linkages between commodity-price and macroeconomic volatility in eight CEE countries, using monthly data that begin in the 1990s. Using Multivariate Generalised Autoregressive Conditional Heteroskedasticity (MGARCH) models, we find that effects differ among the variables of interest, with oil-price fluctuations having less influence on interest-rate volatility than on output, exchange rates and inflation. Results also vary by country type, with the Czech Republic, Hungary, and Poland less likely to see exchange-rate volatility spill over to output variability, and Russia and Ukraine witnessing (perhaps surprisingly) fewer spillovers from oil prices to output.

\section{Relation to the Literature}

Most studies of commodity-price volatility examine either the volatility of one or more commodities itself, or spillovers between commodity and financial prices (such as stocks or currencies). In the former group, Beck (2001) uses an ARCH model to examine storable and non-storable commodities, finding that only storable commodity prices exhibit time-varying variability. Dahl and Iglesias (2009), however, repeat the earlier study and find that non-storable commodities exhibit this property as well. In a seminal study, Cashin et al. (2002) discuss spillovers to the exchange rate for socalled "commodity currencies." Other analyses apply different types of GARCH, as well as alternative estimation methods. For example, Bernard et al. (2008) examine aluminum prices and find that Exponential GARCH or other GARCH methods do not outperform the standard method. Choi and Hammoudeh (2010) apply a number of variations in analysis of the oil and metals markets. Likewise, Ding and Vo (2012) and Brooks and Prokopczuk (2013) use non-GARCH models in their studies.

Studies in the second group mentioned above include Bui and Pippinger (1990), who examine links between commodity prices and (supposedly more volatile) exchange rate regimes, while Smith (1999) studies differences in spillovers under fixed and floating exchange rates. Chen et al. (2010) examine the other direction of causation-from commodity-driven exchange rates to global commodity prices. Mensi et al. (2013) use a VAR-GARCH model to investigate spillovers between stock and commodity prices.

Fewer studies focus on connections between commodity-price volatility and the real economy, although the means of the variables are often included in models when the variances are not. Deaton (1999) finds that commodity prices explain nearly half 
of sub-Saharan Africa's growth during the period of study. Ocran and Biekpe (2007) discuss the sensitivity of policymakers to changes in commodity prices, thus affecting monetary and macroeconomic variables. Velasco and Céspedes (2012) conclude that increases in commodity prices increase economic activity in their analysis.

While Hegerty $(2011,2012)$ examines a single macroeconomic variable (the interest rate and output, respectively) and its volatility transmissions within the CEE region, multivariate analyses are relatively rare. We therefore examine volatility spillovers among oil prices and output growth, inflation, interest rates, and exchange rates in eight CEE economies using a VAR(1)-MGARCH model. This model allows to assess spillovers among the variables in the mean equations as well as in their variances. Our paper proceeds as follows. Section II outlines the econometric methodology. Section III discusses the results, and Section IV concludes.

\section{Methodology}

Using monthly data from the International Financial Statistics of the International Monetary Fund, we calculate log changes in Industrial Production and the Consumer Price Index (after first deseasonalizing both series using the Census-X12 method), money-market interest rates, and the exchange rate expressed as units per U.S. dollar. (For Hungary, the discount rate is used.) The exact sample lengths are provided in Table 2 in Appendix. We also calculate log changes in the index of U.K. Brent oil prices.

Our sample of countries includes CEE economies that have progressed along different paths during the two decades since the fall of communism. Three countries (the Czech Republic, Hungary, and Poland), were early reformers and among the first to join the European Union. The Balkan countries of Bulgaria and Romania joined later, and still face a number of challenges. To this group might be added Croatia, which joined the EU only in 2013. Finally, Russia and Ukraine lie outside the economic bloc, with few prospects of joining in the near future. We expect to find interesting differences among these countries in our study.

Our goal is to measure time-varying volatility and its transmission, based on GARCH models introduced by Engle (1982) and Bollerslev (1986). We model each series simultaneously as follows. For each country, we estimate a Vector Autoregressive model of order one-a VAR(1) - to capture contemporaneous spillovers among the macroeconomic variables and oil prices, as is Equation (1a). At the same time, we estimate a Multivariate $\operatorname{GARCH}(1,1)$ as in Equation (1b), in which each variable's variance series is a function of the others' error terms (shocks to the variables) and volatility series. The resulting coefficients show volatility spillovers from one variable to another. We also estimate conditional correlations, as is shown in Equation (1c): 


$$
\begin{gathered}
{\left[\begin{array}{l}
\Delta e_{t} \\
\Delta r_{t} \\
\Delta y_{t} \\
\Delta c p i_{t} \\
\Delta p_{t}^{\text {Oil }}
\end{array}\right]=\left[C_{5 x 1}\right]_{5 x 5}\left[\begin{array}{l}
\rho \\
\Delta c p i_{t-1} \\
\Delta p_{t-1}^{\text {Oil }}
\end{array}\right]+\left[\begin{array}{l}
\Delta e_{t-1} \\
\Delta r_{t-1} \\
\varepsilon_{t}
\end{array}\right]} \\
\ln \sigma_{i, t}^{2}=\alpha_{i, 0}+\sum_{j}^{n}\left(\alpha_{i, j} \phi_{i} \varepsilon_{i, t-1}^{2}+\beta_{i, j} \ln \sigma_{j, t-1}^{2}\right) \quad \text { for all } \mathrm{i}, \mathrm{j} \\
\sigma_{i, j, t}=\gamma_{i, j} \sigma_{i, t} \sigma_{j, t} \text { for all } \mathrm{i}, \mathrm{j} ; \mathrm{i} \neq \mathrm{j}
\end{gathered}
$$

This estimation method allows us to find evidence of volatility spillovers both from oil prices to the overall macroeconomy, as well as among the macroeconomic variables themselves. We discuss our findings below.

\section{Results}

We begin by modeling oil-price volatility using a univariate GARCH(1,1) model. Applying the Box-Jenkins methodology, we find that a simple AR(1) serves as an appropriate mean equation. The original series of log changes and the resulting variance series are depicted in Figure 1. Besides the sharp price declines associated with the 2008 financial crisis, we see relatively high volatility in the late 1990s and early- and mid-2000s.

Figure 1: Oil-Price Log Changes and Oil-Price Volatility, 1991-2014
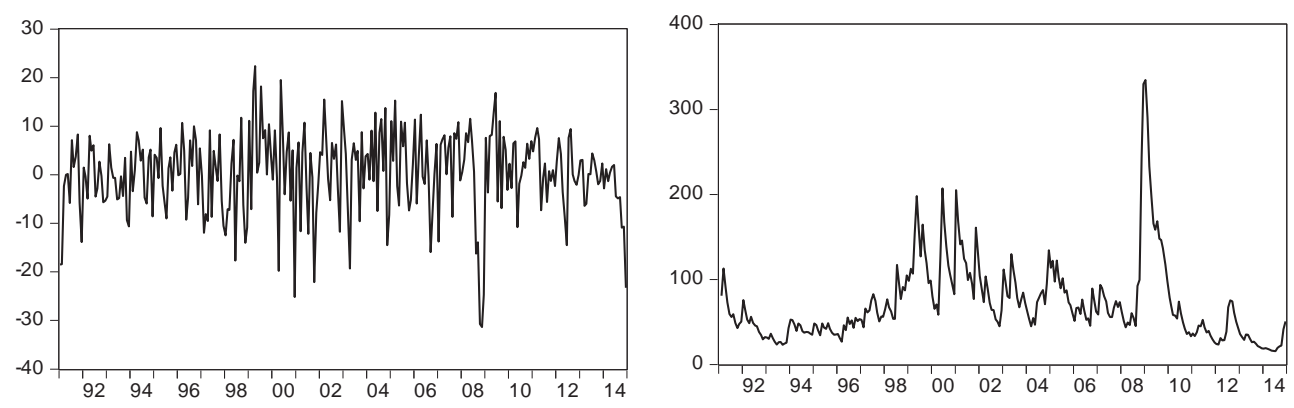

Calculated based on a GARCH(1,1) process on an AR(1) estimation of log changes in U.K. Brent oil prices. 
Figure 2 shows all eight countries' macroeconomic time series. We see sharp currency depreciations in Croatia (1992), Romania (1997), Russia (1998), and Ukraine (2008). As international macroeconomic theory would predict, inflation is high during these periods as well. We see fluctuations in growth rates throughout the region over the entire sample, while interest rates exhibit particularly obvious time-varying volatility in Croatia, Romania, Bulgaria, and Russia. We also see inflation stabilise in Russia, Croatia, and Romania (Bulgaria's sample begins after its 1997 hyperinflation, and Ukraine's sample is short as well). Differences among countries suggests that the relative contribution of domestic factors versus oil prices toward macroeconomic fluctuations will vary across the region.

Figure 2: Macroeconomic Variables (Monthly Log Changes)

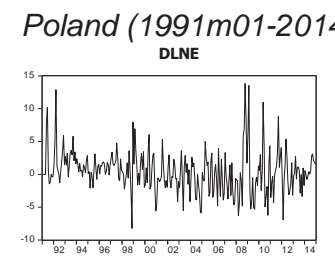

GROWTH

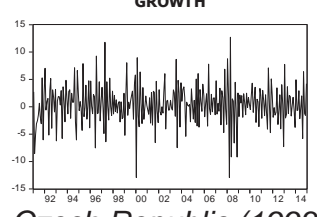

Czech Republic (1993m02-2014m11)

DLNE

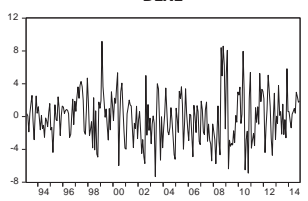

GROWTH

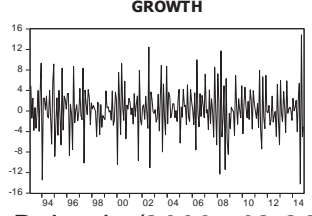

Bulgaria (2000m02-2014m08)

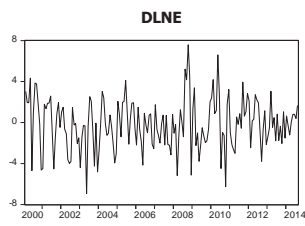

INF

DLNR

DLNR
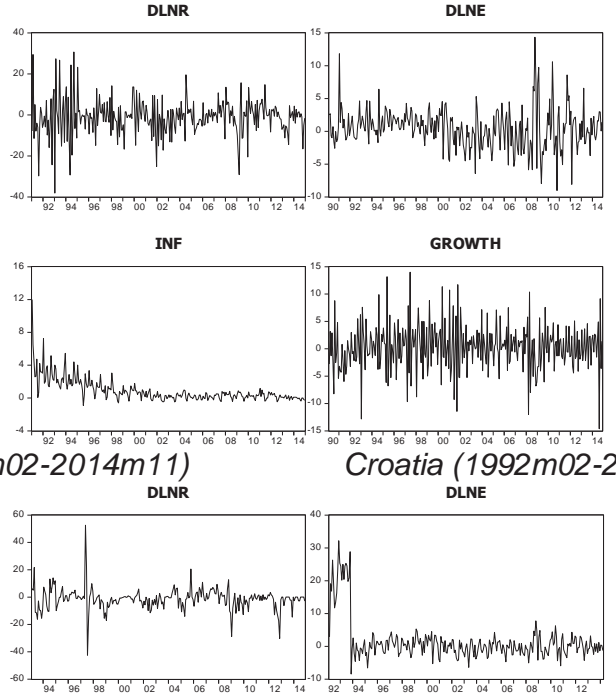

GROWTH
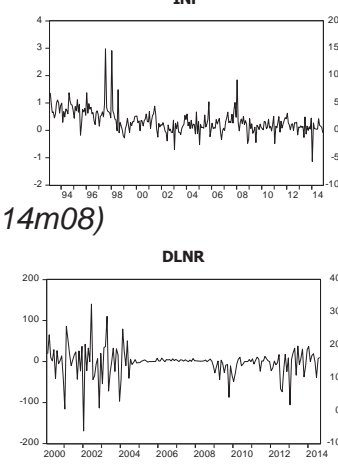

GROWTH

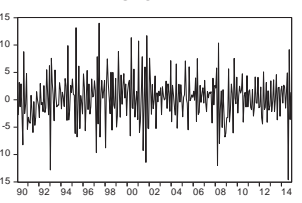

Hungary (1990m02-2014m11)
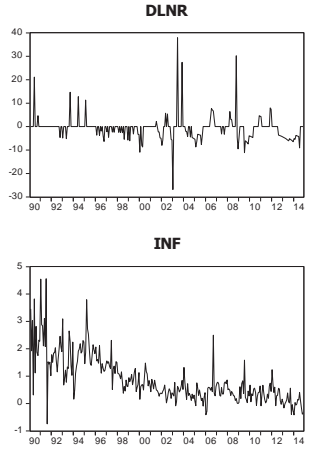

$4 m 3$ )

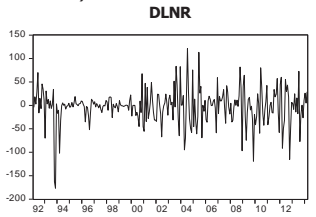

INF

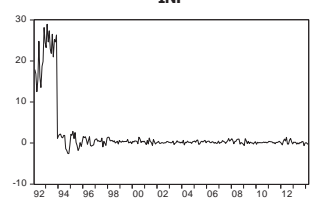

Romania (1995m01-2014m11)

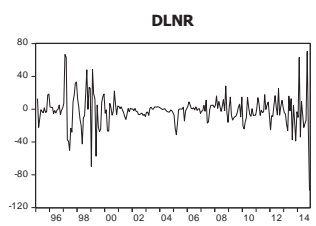



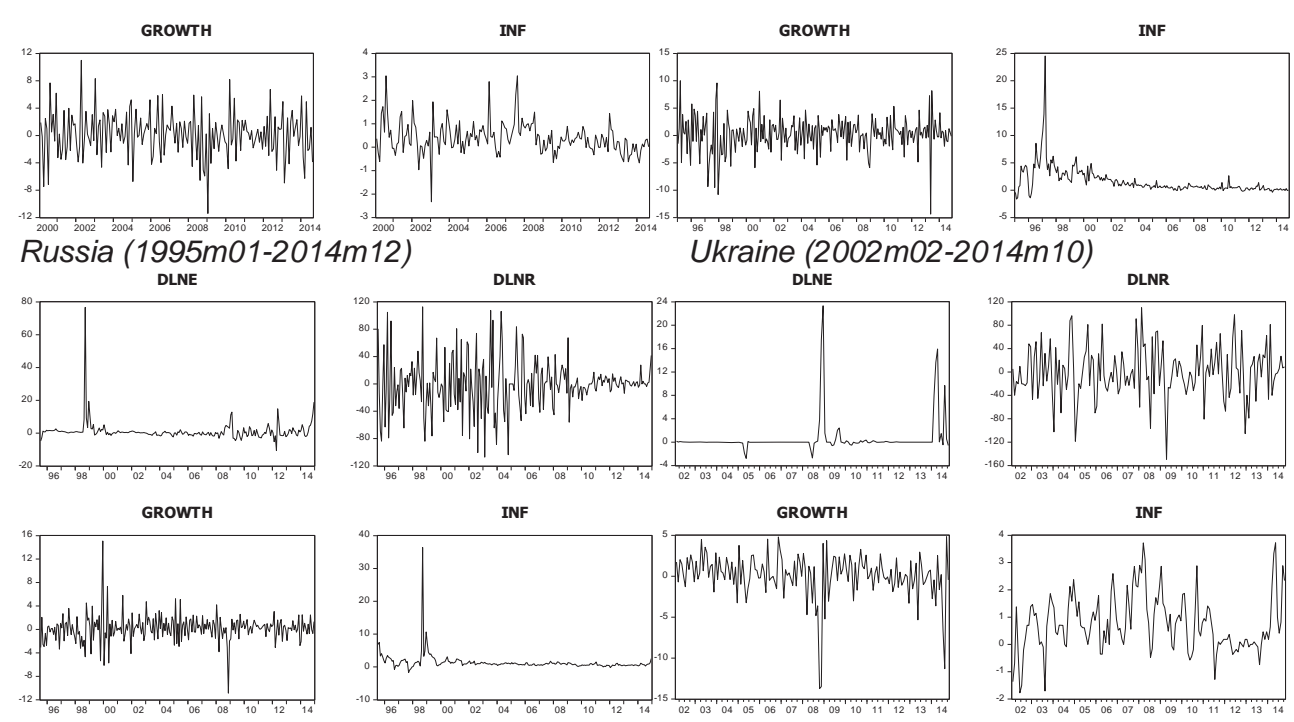

These contributions are tested using our VAR(1)-MGARCH(1,1) model, the results of which are presented in Table 1 in Appendix. While our focus is on spillovers that originate with oil prices, we also note key connections among macroeconomic variables. We focus on three main ideas when interpreting these statistics: Contemporaneous connections in the mean equation (the VAR coefficients from Equation 1a), conditional correlations (Equation 3c), and the GARCH coefficients (Equation 3b). We suspect that our three groups of countries (the "Visegrad" countries that joined the EU in 2004, the three Balkan nations, and Russia and Ukraine) exhibit differences in their behavior, which might be attributed to varying degrees of transition and economic integration. We address these differences below.

In the mean equations, we see spillovers from oil prices to inflation in Poland and Hungary (manufacturing exporters that were early EU members). These two countries see the same connection from inflation to their currencies. Among the Balkan nations, and in Russia and Ukraine, there are fewer significant effects. Likewise, oil-price increases boost industrial production growth in Hungary and Ukraine, and inflation in Hungary and Poland. Only Russia sees its currency decline (an increase in units per dollar) if oil prices fall.

Do these connections among the mean equations also exist among the variances? Turning to the conditional correlations, oil-price and exchange-rate volatility are negatively correlated in all cases but Ukraine. This is perhaps surprising because the sign is "wrong," suggesting that increased global risk is related to more currency stability, but perhaps policymakers are more active in times of turmoil. This discrepancy is worthy of further study. While Ukraine is perhaps more susceptible to political and other risk than to events in world oil markets, we see few easily explainable patterns 
among any pairs of macroeconomic variables in the region. For example, oil-price volatility is correlated with interest-rate volatility in Poland and Russia (suggesting that policymakers are active in their response to risk), but no other nation shows the same relationship. Likewise, inflation volatility is correlated with output growth volatility only in the Czech Republic, and is correlated with the exchange rate in Hungary, Russia, and Ukraine. These findings are easier to explain using Equation (1b).

Examining the GARCH coefficients, we find clear evidence of volatility spillovers from oil prices to all macroeconomic variables, for almost all countries. Only interest-rate volatility fails to yield significant GARCH coefficients for Poland, Croatia, and Bulgaria, while Russia's and Ukraine's exchange-rate equations do not have significant oil-price volatility coefficients. Perhaps this can be explained by the fact that these two non-EU members are highly sensitive to energy prices and also manage their exchange rates heavily. Clearly, these two countries behave differently with regard to their responses to oil prices; these differences are explained in further detail below.

Other macroeconomic variables show contributions to each other's volatilities, but not uniformly across countries or variables. For example, Polish interest-rate variability is influenced by all domestic variables, but not by oil-price volatility. On the other hand, Polish growth and inflation, as well as all Hungarian variables, see numerous significant impacts. For the other countries, Russia and Ukraine appear to have the least number of significant coefficients.

Table 2 summarises the GARCH coefficients and conditional correlations by country group and in total. Oil-price volatility spills over to exchange rates and inflation, and interest-rate volatility affects exchange-rate volatility, in seven of the eight countries. Oil prices affect output in six cases. On the other hand, oil price fluctuations influence interest rates in only half the countries. Exchange-rate volatility affects output variability in only three cases, none of which are the early EU members in Group A. Output variability spills over to exchange rates and interest rates in only three cases each. Group C (Russia and Ukraine) experience few spillovers from other variables, other than from oil prices to inflation volatility.

In addition, calculating sums for each group in Table 2 shows that while Group A (Poland, Hungary, and the Czech Republic) has 33 significant coefficients and Group B (the three Balkan countries) has 34, the two countries in Group C generate only 11 significant coefficients. This is proportionally less than is the case for the two larger groups. This suggests that political factors or other unexplained variables might be responsible for much of the macroeconomic risk. Considering that five of these 11 coefficients are related to the oil price, we can conclude that this variable plays a particularly large role in macroeconomic volatility in this part of the region.

Finally, a look at the summary of conditional correlations shows the most linkages to be between exchange rates and inflation. Differences between the groups with regard to the other variable pairs suggest that the level of integration might help explain differing degrees of susceptibility to macroeconomic spillovers. 


\section{Conclusion}

Following years of record highs, the continued drop in oil prices that began in 2014 has helped contribute to increased volatility and risk in the CEE region. This risk has had profound economic and political effects. The former can be examined using time-series techniques. Using Multivariate GARCH methods and a VAR(1) mean equation, we address spillovers from oil-prices to fluctuations elsewhere in the macroeconomies of eight CEE nations. Our VAR(1) mean equations show that Poland and Hungary experience spillovers from oil prices to inflation and from inflation to the exchange rate, while the Russian ruble depreciates if oil prices fall.

Our GARCH coefficients and conditional correlations find that oil-price volatility spills over less to interest-rate risk than to the other variables, and that other types of macroeconomic volatility play a far smaller role in the Russian and Ukrainian economies than in the Visegrad or Balkan nations. For these two countries, oil prices have significant effects, although, perhaps surprisingly, not on the ruble or hryvnia. We can therefore conclude that the degree of success in the transition process-which has rewarded most of these countries with membership in the EU-also might help explain these varying results. Russia and Ukraine, in particular, show results that are worthy of further study.

\section{REFERENCES:}

Beck, S. (2001). Autoregressive conditional heteroscedasticity in commodity spot prices. Journal of Applied Econometrics, 16(2), 115-132.

Bernard, J.-T., Khalaf, L., Kichian, M., \& Mcmahon, S. (2008). Forecasting commodity prices: GARCH, jumps, and mean reversion. Journal of Forecasting, 27(4), 279-291.

Bollerslev, T. (1986). Generalized autoregressive conditional heteroscedasticity. Journal of Econometrics, 31, 307-327.

Brooks, C. \& Prokopczuk, M. (2011). The dynamics of commodity prices. Quantitative Finance, 13(4), 527-542.

Bui, N. \& Pippenger, J. (1990). Commodity prices, exchange rates and their relative volatility. Journal of International Money and Finance, 9(1), 3-20.

Cashin, P., Céspedes, L. \& Sahay, R. (2002). Keynes, cocoa and copper: In search of commodity currencies. IMF Working Paper Series WP/02/223.

Céspedes, L.F., and Velasco, A. (2012). Macroeconomic performance during commodity price booms and busts. IMF Economic Review, 60(4), 570-599.

Chen, Y.-C., Rogoff, K. \& Rossi, B. (2010). Can exchange rates forecast commodity prices? Quarterly Journal of Economics, 125(3), 1145-1194.

Choi, K. \& Hammoudeh, S. (2010). Volatility behavior of oil, industrial commodity and stock markets in a regime-switching environment. Energy Policy, 38(8), 4388-4399.

Dahl, C.M., \& Iglesias, E.M. (2009). Volatility spillovers in commodity spot prices: New empirical results. Economic Modelling, 26(3), 601-607.

Deaton, A. (1999). Commodity prices and growth in Africa. Journal of Economic Perspectives, 13(3) 23-40. 
Ding, L. \& Vo, M. (2012). Exchange rates and oil prices: A multivariate stochastic volatility analysis. The Quarterly Review of Economics and Finance, 52(1), 15-37.

Engle, R.F. (1982). Autoregressive conditional heteroscedasticity with estimates of the variance of the United Kingdom inflation. Econometrica, 50, 377-403.

Hegerty, S.W. (2011). Interest-Rate volatility and volatility spillovers in emerging Europe. International Review of Applied Economics, 25(5), 599-614.

Hegerty, S.W. (2012). Output volatility and its transmission in transition economies: Implications for European integration. Journal of Economic Integration, 27(4), 520-536.

Mensi, W., Beljid, M., Boubaker, A., \& Managi, S. (2013). Correlations and volatility spillovers across commodity and stock markets: Linking energies, food, and gold. Economic Modelling, 32, $15-22$.

Ocran, M. \& Biekpe, N. (2007). The role of commodity prices in macroeconomic policy in South Africa. South African Journal of Economics, 75(2), 213-220.

Smith, C. E. (1999). Exchange rate variation, commodity price variation and the implications for international trade. Journal of International Money and Finance, 18(3), 471-491. 
斑

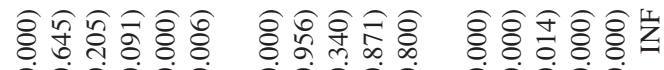

èं $\dot{e} \dot{0}$

è巳e

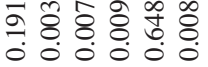

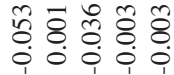

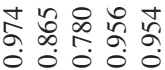

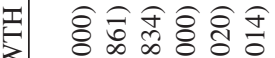

$\dot{e} \dot{e} \dot{e} \dot{e} \dot{e}$

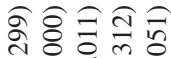

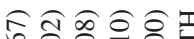

e $\dot{e} \dot{e}$

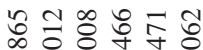

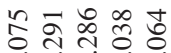

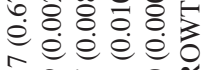

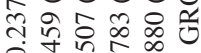

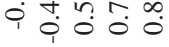

0
$\infty$
$\infty$
$\vdots$
$\vdots$
$\vdots$
0
0

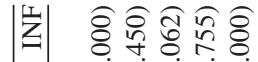

èe é

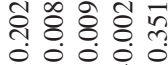

- o i i io

i o o i

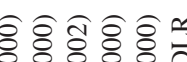

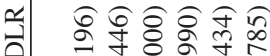

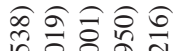

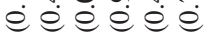

èंe

e $\dot{0} \dot{0}$

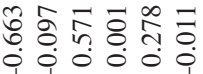

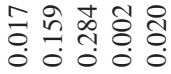

串号: 잉

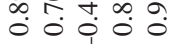

ํํㅇ

e

藏客

I

èंe

考额范寺

- :0. 이

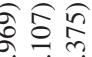

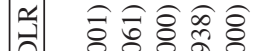
eं $\dot{e} \dot{e}$

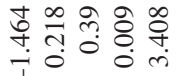

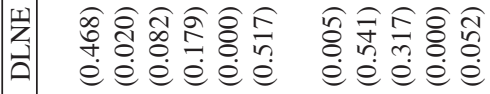

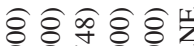

è

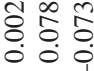

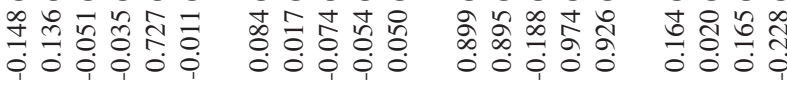

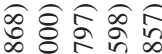

eे巳巳巳e

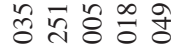

궁ํ.

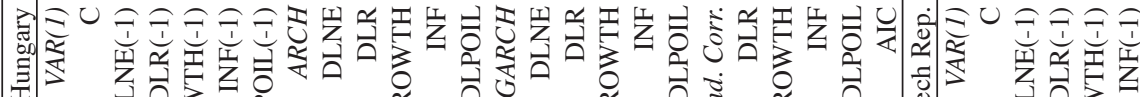

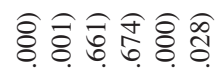

eं $\stackrel{\dot{e}}{\dot{e}} \dot{e}$

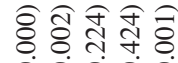

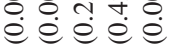

के

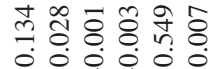

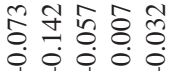

$\dot{e} \dot{e} \dot{e}$

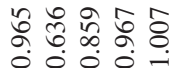

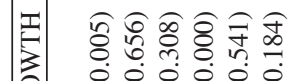

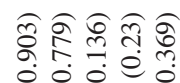

苫

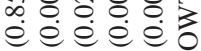

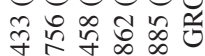

:

i०००0:0

$\approx$

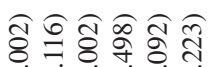

eं巳e巳

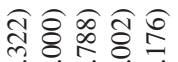

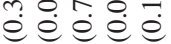

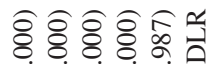

e $\dot{e} \dot{e} \dot{e}$

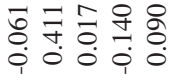

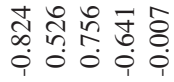

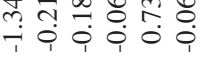

ปे

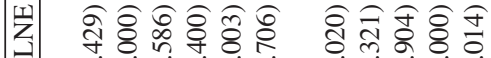

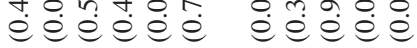

甹

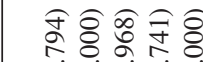

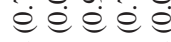

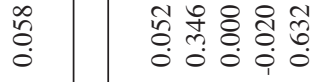

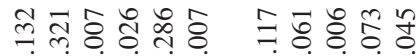

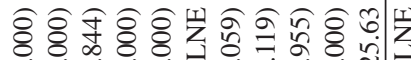

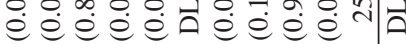

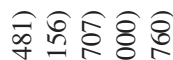

$\dot{e} \dot{e} \dot{e} \dot{e}$

: 0.000

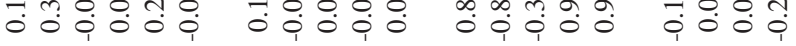

สิ

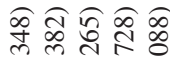

é巳巳巳巳

융응

$\because 000 \div$

क人

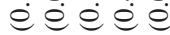

तิ่

i००००0

竞

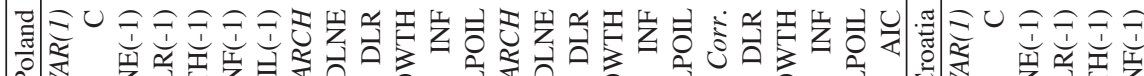

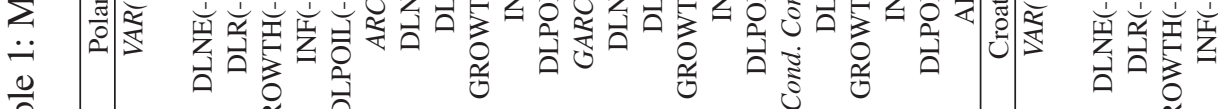

$\frac{\sqrt{0}}{\frac{\pi}{0}}$ 


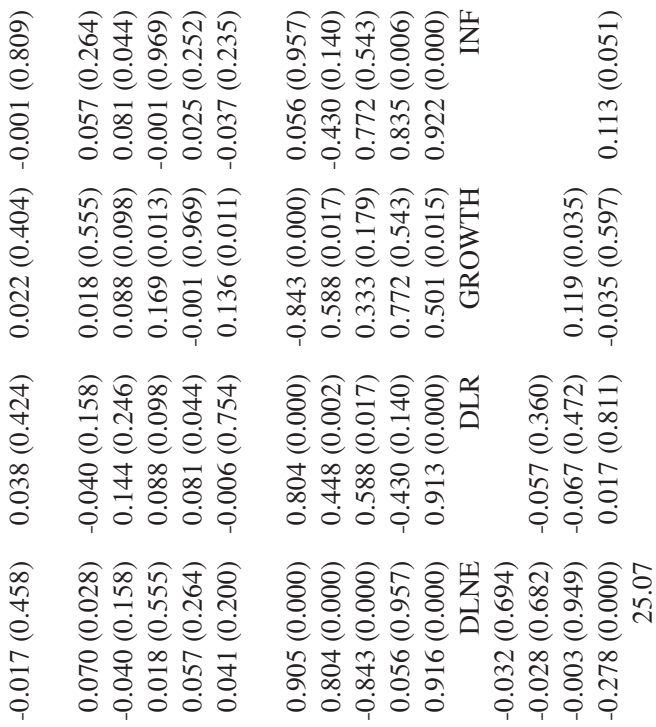

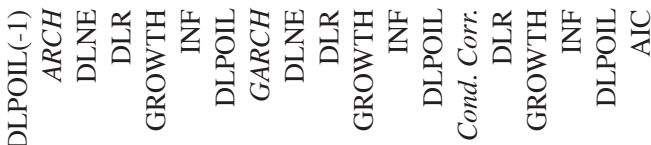

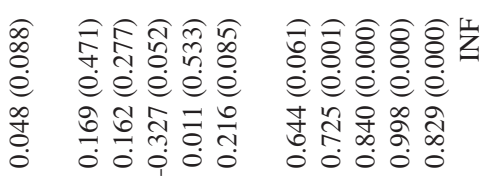

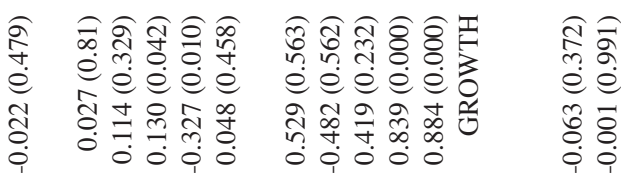

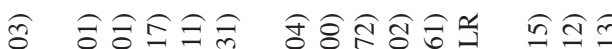

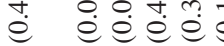

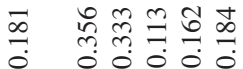

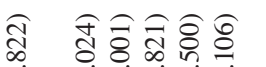

é

\& 守 母.

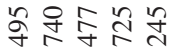
००0ㅇํㅇ

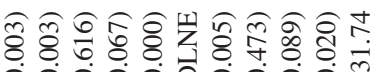

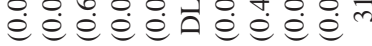

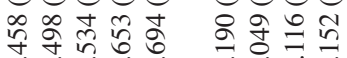

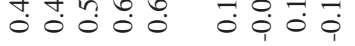

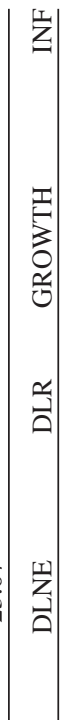

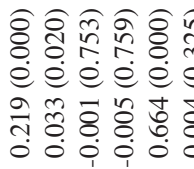

कิ

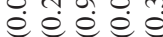

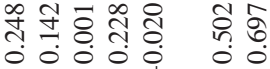

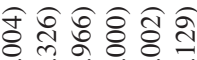

तิ

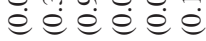

००००:

ते

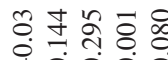

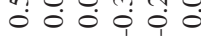

iै

ڤิ)

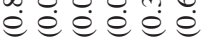

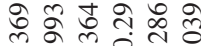

สิชิซิ์ ซิ

仓̊

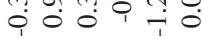

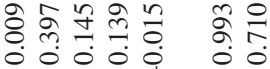

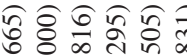

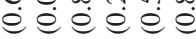

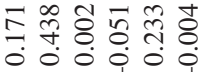

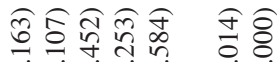

eे巳巳巳巳

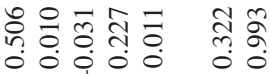

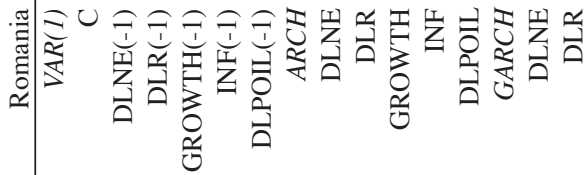

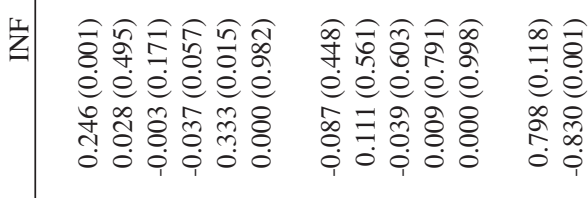

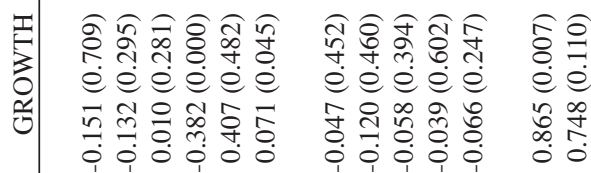

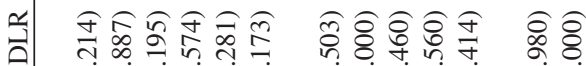

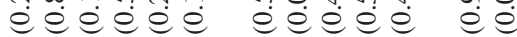

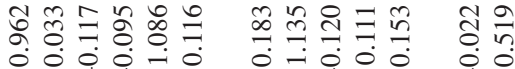

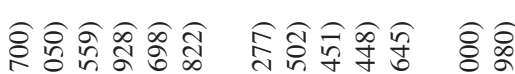

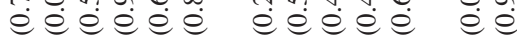

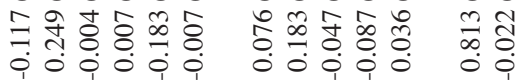

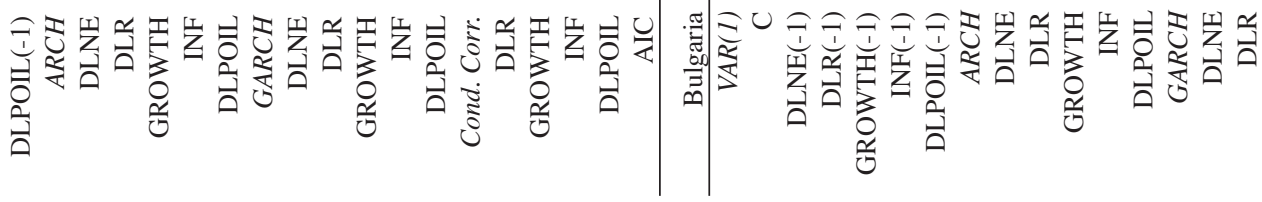




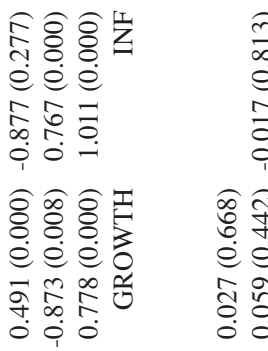

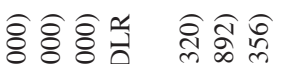

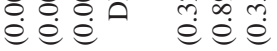

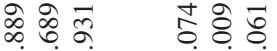
पं०० 00 ००

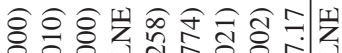
é巳è

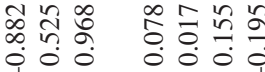

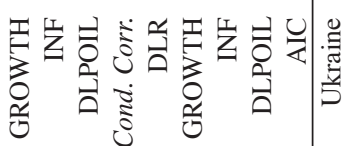

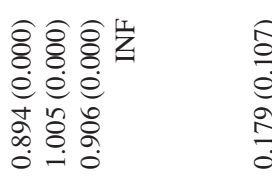

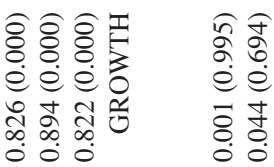

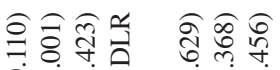

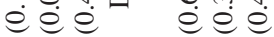

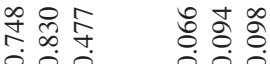
०ं० ००

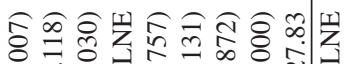

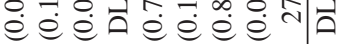
苍余占 की 000000

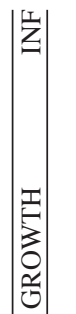

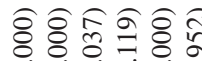

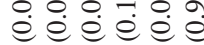

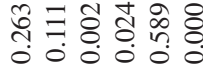

ฉิ)

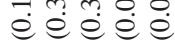
는 ㅇำชิ

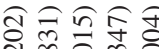
e 巳 è巳

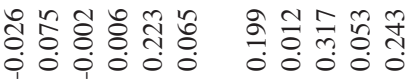
eेèe क्षิ e巳巳e eे

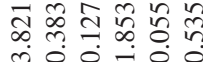
लं $0 \div$ i ซิㅎํㅇㅎㅇ을 eे巳è

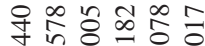

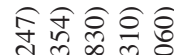

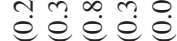

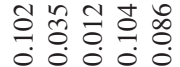

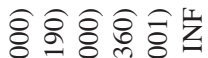
eे巳e $巳$

ปั่ 0.

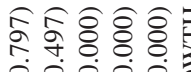
eे巳e@

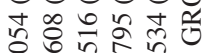

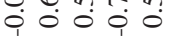

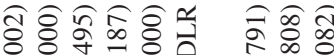
eेe巳巳 8 \% :0 융ำ

응 สิ์ ิิ eे巳e ต ํํㅇำ

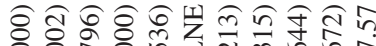

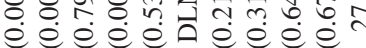
तิ: ○00

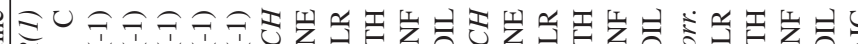

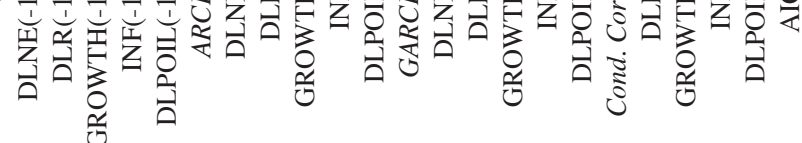

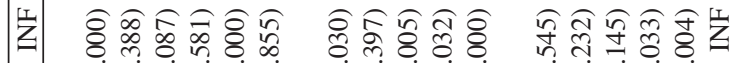

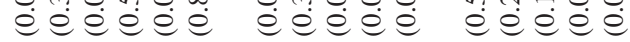

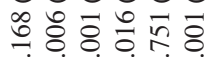

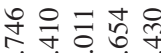

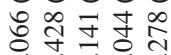

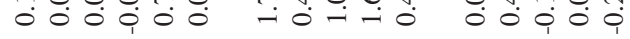

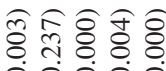

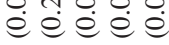
eे巳e $\dot{e} \dot{e}$

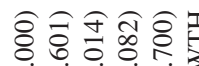
ê

ก กิ

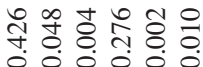

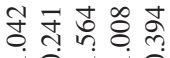

iे

옹

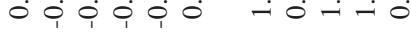

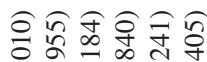

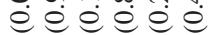

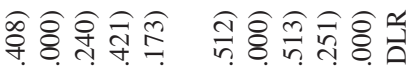
eे巳巳e

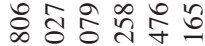
กิㅋํำ e é巳e तิ eे mi०

$\circ \div 000$

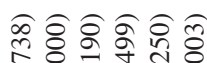

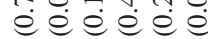

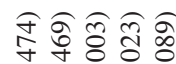
eे巳e $\dot{e} \dot{e}$ 은

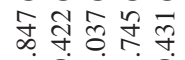

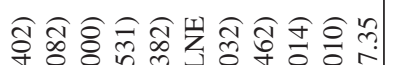

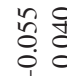

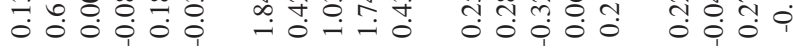

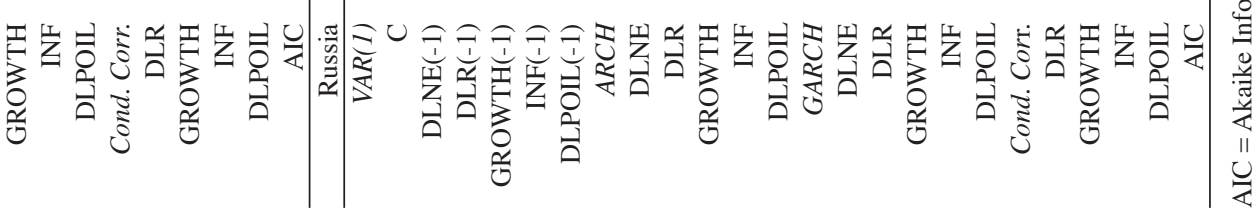


Table 2: Summary of Significant GARCH Coefficients (by country group)

E volatility caused by

\begin{tabular}{rrrrrrrrrrrrrrrrrr}
$E$ & $r$ & \multicolumn{1}{c}{} & \multicolumn{1}{c}{$Y$} & \multicolumn{1}{c}{ Inf } & \multicolumn{1}{c}{$P($ Oil $)$} \\
\hline & A & B & C & All & A & B & C & All & A & B & C & All & A & B & C & All \\
& 3 & 2 & 2 & 7 & 1 & 2 & 0 & 3 & 2 & 1 & 1 & 4 & 3 & 3 & 1 & 7
\end{tabular}

r volatility caused by

\begin{tabular}{|c|c|c|c|c|c|c|c|c|c|c|c|c|c|c|c|c|c|c|c|}
\hline E & & & & $r$ & & & & $Y$ & & & & $\operatorname{Inf}$ & & & & & il) & & \\
\hline A & B & $\mathrm{C}$ & All & & & & & A & B & $\mathrm{C}$ & All & A & B & $\mathrm{C}$ & All & $\mathrm{A}$ & B & $\mathrm{C}$ & All \\
\hline 2 & 2 & 2 & 6 & & & & & 2 & 1 & 0 & 3 & 3 & 3 & 0 & 6 & 1 & 1 & 2 & 4 \\
\hline \multicolumn{20}{|c|}{ Y volatility caused by } \\
\hline$E$ & & & & $r$ & & & & $Y$ & & & & $\operatorname{Inf}$ & & & & & il) & & \\
\hline A & $\mathrm{B}$ & $\mathrm{C}$ & All & A & $\mathrm{B}$ & $\mathrm{C}$ & All & & & & & A & B & $\mathrm{C}$ & All & A & B & $\mathrm{C}$ & All \\
\hline 0 & 2 & 1 & 3 & 2 & 1 & 0 & 3 & & & & & 2 & 3 & 0 & 5 & 3 & 3 & 0 & 6 \\
\hline \multicolumn{20}{|c|}{ Inflation volatility caused by } \\
\hline$E$ & & & & $r$ & & & & $Y$ & & & & $\operatorname{Inf}$ & & & & & il) & & \\
\hline A & B & $\mathrm{C}$ & All & A & $\mathrm{B}$ & $\mathrm{C}$ & All & A & B & $\mathrm{C}$ & All & & & & & A & B & $\mathrm{C}$ & All \\
\hline 2 & 2 & 0 & 4 & 3 & 3 & 0 & 6 & 2 & 2 & 0 & 4 & & & & & 2 & 3 & 2 & 7 \\
\hline
\end{tabular}

Conditional Correlations

\begin{tabular}{lrrrr} 
& A & B & C & All \\
\hline E-r & & 1 & 1 & 2 \\
E-Y & & & 1 & 1 \\
E-Inf & 3 & 3 & 1 & 7 \\
E-P(Oil) & & & & 0 \\
r-Y & & & & 0 \\
r-Inf & & & & 0 \\
r-P(Oil) & 1 & & & 1 \\
Y-Inf & 1 & & & 1 \\
Y-P(Oil) & & & & 0 \\
Inf- & & & & \\
P(Oil) & & & & 0 \\
\hline
\end{tabular}

Group A: Czech Republic, Hungary, Poland

Group B: Croatia, Romania, Bulgaria

Group C: Russia, Ukraine

"All": The eight countries in the combined sample. 
